九州大学学術情報リポジトリ

Kyushu University Institutional Repository

\title{
Survey of Apple Chlorotic Leaf Spot Virus and Apple Stem Grooving Virus Occurrence in Korea and Frequency of Mixed Infections in Apple
}

Han, Jae-Yeong

Department of Applied Biology, College of Agriculture and Life Sciences, Chungnam National University

Kim, Jung-Kyu

Department of Applied Biology, College of Agriculture and Life Sciences, Chungnam National University

Cheong, Jin-Soo

Department of Applied Biology, College of Agriculture and Life Sciences, Chungnam National University

Seo, Eun-Yeong

Department of Applied Biology, College of Agriculture and Life Sciences, Chungnam National University

他

https://doi.org/10.5109/1526391

出版情報：九州大学大学院農学研究院紀要. 60 (2)，pp.323-329，2015-09-18. Faculty of Agriculture, Kyushu University

バージョン：

権利関係 : 


\title{
Survey of Apple Chlorotic Leaf Spot Virus and Apple Stem Grooving Virus Occurrence in Korea and Frequency of Mixed Infections in Apple
}

\author{
Jae-Yeong HAN ${ }^{1}$, Jung-Kyu KIM${ }^{1}$, Jin-Soo CHEONG ${ }^{1}$, Eun-Yeong SEO ${ }^{1}$, Chan-Hwan PARK ${ }^{1}$, \\ Hye-Kyeong $\mathrm{JU}^{1}$, In Sook $\mathrm{CHO}^{2}$, Takafumi GOTOH, Jae Sun MOON ${ }^{3,4}$, \\ John HAMMOND ${ }^{5 *}$ and Hyoun-Sub LIM ${ }^{1 *}$
}

Kuju Agricultural Research Center, Faculty of Agriculture, Kyushu University, Kuju, Oita, 878-0201, Japan

(Received May 8, 2015 and accepted May 19, 2015)

\begin{abstract}
Due to the absence of knowledge of the distribution of Apple stem grooving virus (ASGV) and Apple chlorotic leaf spot virus (ACLSV) in apples in Korea, we carried out a survey for these viruses in Gyeongsang and Chungcheong provinces in 2014. A total of 65 samples were collected and tested by RT-PCR using ASGV and ACLSV specific primers. ASGV was detected in 22 samples, and ACLSV in three samples; two of the samples showed double infection of ASGV and ACLSV. Phylogenetic analysis suggests that Korean ASGV and ACLSV were introduced from other countries. Prevalence of ASGV and ACLSV indicates that virus prevention and control may be poorly managed in orchards. Since fruit trees remain in the orchard for many years and it is not possible to eliminate virus from infected trees, healthy scions and virus-resistant rootstocks must be used for virus control. Because it is difficult to visually distinguish ASGV-infected and ACLSV-infected apple trees from healthy trees, thorough surveys by molecular biology methods must be performed routinely.
\end{abstract}

Key words: Apple stem grooving virus, Apple chlorotic leaf spot virus, double infection, RT-PCR

\section{INTRODUCTION}

Apple (Malus domestica) belongs to the family Rosaceae and is cultured worldwide. About 10 cultivars are cultured in Korea. Outdoor fruit tree cultivation area in Korea was 153,415 ha, and the apple tree cultivation area was 30,702 ha, which is the largest component of the fruit cultivation area (Statistics Korea, 2014). The main production areas of apple in Korea are Gyeongsang Province and Chungcheong Province which account for $92 \%$ of the domestic apple output (Statistics Korea, 2014)

Apple stem grooving virus (ASGV) and Apple chlorotic leaf spot virus (ACLSV) are major viruses causing economic damage to apples (Campbell, 1963; Posnette et al., 1963; Zahn, 1996) and significant annual losses have been reported. ASGV is the type species of the genus Capillovirus. The genome is positive sense single stranded RNA with a length of about 6,495-6,497 nucleotides (Yoshikawa et al., 1992) excluding the poly(A) tail. The viral RNA has 2 ORFs; ORF1 encodes

\footnotetext{
Department of Applied Biology, College of Agriculture and Life Sciences, Chungnam National University, Daejeon 305-764, Korea

Horticultural \& Herbal Crop Environment Division, National Institute of Horticultural \& Herbal Science, RDA Suwon 441440, Korea

Greenbio research center, Korea Research Institute of Bioscience and Biotechnology, Daejeon 305-333, Korea

4 Department of Biosystems and Bioengineering, University of Science and Technology, Daejeon 305-350, Korea

United States Department of Agriculture - Agricultural Research Service, United States National Arboretum, Floral and Nursery Plants Research Unit, Beltsville, MD 20705, USA

1* Corresponding Author (E-mail: hyounlim@cnu.ac.kr)

5* Corresponding Author (E-mail: john.hammond@usda.ars.gov)
}

a Replication-associated protein and a coat protein (CP) $(27 \mathrm{kDa})$ which is expressed from subgenomic RNA (Tatineni et al., 2009). ORF2 encodes a movement protein $(36 \mathrm{kDa})$ in a different reading frame from ORF1. ACLSV is the type species of the genus Trichovirus, and has a positive sense single strand RNA genome of about 7,474-7,555 nucleotides excluding the poly(A) tail (German et al, 1990; Sato et al., 1993). The viral RNA has 3 ORFs; ORF1 encodes a replication-associated protein, ORF2 encodes a movement protein (MP) (50 kDa), and ORF3 encodes a coat protein (21 kDa).

These two viruses are the major pathogens of apple which induce topworking disease (Schmidt, 1972; Wang et al., 2011). Typically, visible symptoms do not appear except in some cultivars (Nemeth, 1986). Both viruses can concurrently infect one host, causing greater damage to fruit production than either single virus infection (Campbell, 1963; Cembali et al., 2003). The worldwide occurrence of ASGV and ACLSV has been reported, especially in China (Pūpola et al., 2011; Song et al., 2011; Wang et al., 2011; Kumar et al., 2012; Ji et al., 2013; Duan et al., 2014; Liu et al., 2013, 2014). In Korea, the occurrence has also been reported (Park et al., 2006; Cho et al., 2010; Kim et al., 2011). The distribution of ASGV and ACLSV has not been studied in Korea after 2010. There was a previous report of nucleotide sequence of Korean ASGV isolates (Shim et al., 2004) but not of ACLSV isolates. In order to investigate management condition of apple ochards after 2010, our research team performed virus diagnosis for apple samples collected from Gyeongsang Province and Chungcheong Province in 2014. Also, we identified complete nucleotide sequences of Korean ASGV CP and ACLSV MP in order to phylogenetically compare Korean isolates to those from other countries. These results provide data on the prevalence 
and potential introduction route of these viruses, and should aid establishment of prevention measures, as well as providing primary data for characterization of these apple viruses.

\section{MATERIALS AND METHODS}

\section{SAMPLE COLLECTION}

Collection of samples was performed from May to November of 2014 (Figure 1). ASGV and ACLSV do not induce characteristic symptoms. Thus, leaves and fruits of apple trees showing reduced production, declining health, poor coloring, malformation and maldevelopment, which are considered normal virus effects, were selected (Figure 2). A total of 65 samples were collected from Gyeongsang Province and Chungcheong Province apple orchards

\section{DIAGNOSIS}

Total RNAs of collected samples were extracted by a minor revision of the Cetyltrimethylammonium bromide (CTAB) isolation method (Chang et al., 1993) and cDNAs were synthesized using RevertAid Reverse Transcriptase (Thermo Fisher Scientific Inc.). Primers for ASGV diagnosis were designed based on ASGV coat protein nucleotide sequence (Accession number: D14995) from National Center for Biotechnology Information (NCBI), and primers for ACLSV diagnosis were those reported by Menzel et al. (2002) (Table 1). RT-PCR was performed

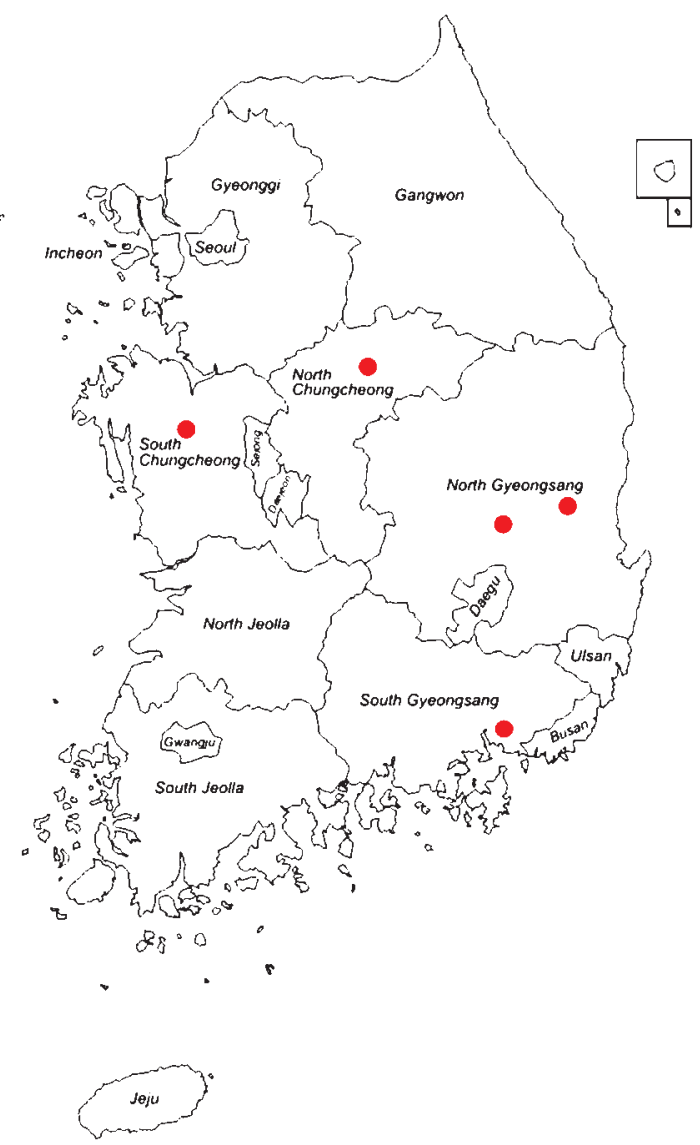

Fig. 1. Geographical distribution of apple sample collection sites. in a $20 \mu \mathrm{l}$ total volume containing $1 \mu \mathrm{l} \mathrm{cDNA}, 10$ pmol of each primers, $2 \mu \mathrm{l}$ of $10 \mathrm{X}$ Reaction Buffer, $2 \mu \mathrm{l}$ of $10 \mathrm{mM}$ dNTPs mixture and 1 unit of Prime Taq (GENET BIO CO., Ltd) or Blend Taq ${ }^{\circledR}$ (Toyobo CO., Ltd). The PCR conditions were as follows: 5 minutes at $94^{\circ} \mathrm{C}$ for predenaturing, 35 cycles of 30 seconds at $94^{\circ} \mathrm{C}$ for denaturing 30 seconds at $56^{\circ} \mathrm{C}$ for annealing, and 30 seconds at $68^{\circ} \mathrm{C}$ for extension, followed by 5 minutes at $68^{\circ} \mathrm{C}$ for final extension. Plants were recorded as positive if PCR products of the expected sizes (Table 1) were obtained, and no products were obtained from negative controls.

\section{POLYMERASE CHAIN REACTION, CLONING, SEQUENCING}

The ASGV CP gene and ACLSV MP gene were amplified from all of virus positive samples using above cDNAs and appropriate virus-specific primers. PCR was performed as described above, except that 30 cycles were carried out, with a 1 minute extension time for ASGV $\mathrm{CP}$, and 1 minute 30 seconds for ACLSV MP amplification. The PCR products were visualized in $1 \%$ agarose gel stained with ethidium bromide under UV light. The PCR products were cloned into pGEM $^{\circledR}-\mathrm{T}$ Easy vector

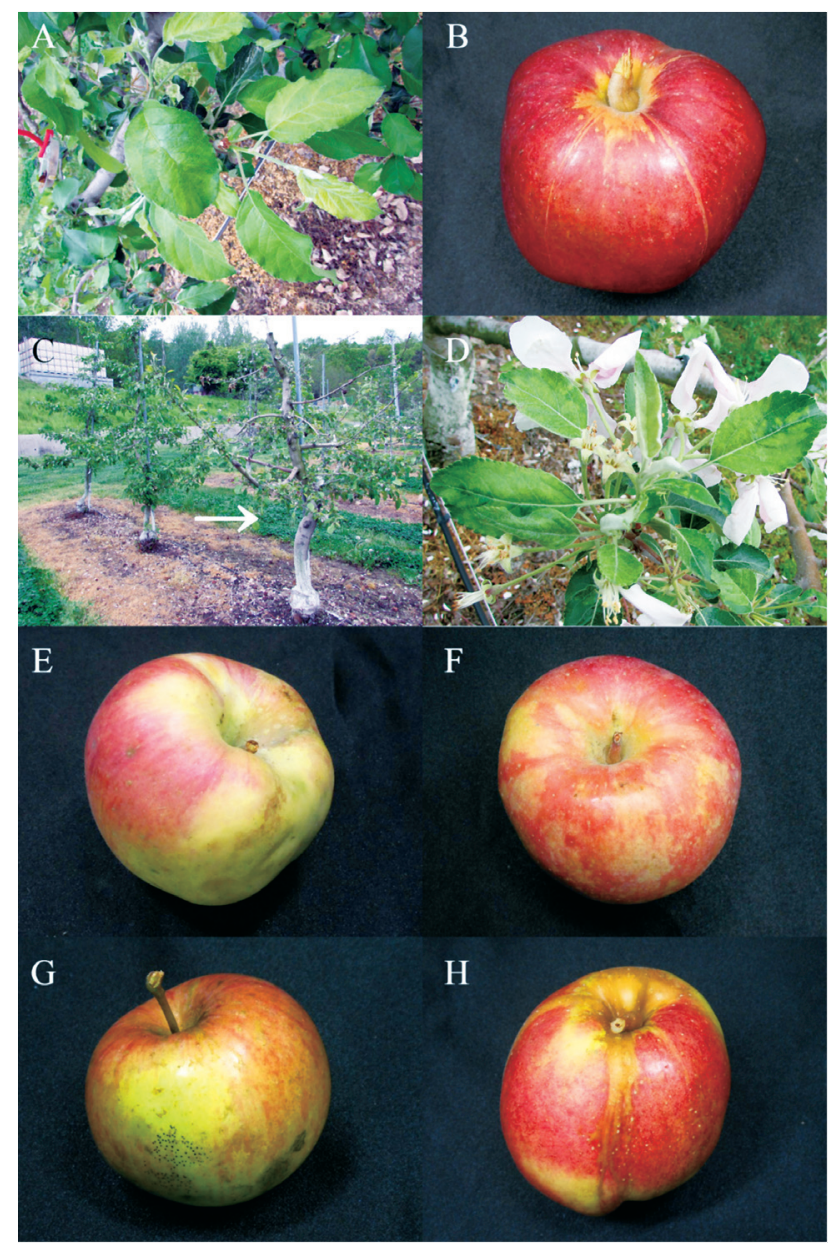

Fig. 2. Various symptoms of collected samples. Apple chlorotic leaf spot virus (ACLSV) and Apple stem grooving virus (ASGV) Double infected leaves (A) and fruit (B); ACLSV infected tree showing shorter height than surrounding trees and pale green leaf color (white arrow)(C); ASGV infected leaves (D) and fruits (E, F, G and H). 
Table 1. Primers used in this study

\begin{tabular}{|c|c|c|c|c|}
\hline Virus & Name & Sequence $\left(5^{\prime}->3^{\prime}\right)$ & Feature & Expected size \\
\hline \multirow{8}{*}{ ASGV } & \multicolumn{4}{|l|}{ For ASGV diagnosis } \\
\hline & ASGV_F (5'oligo) & CATCTGATAAGACCCAGTTTCC & \multirow{4}{*}{ Menzel et al (2002) } & \multirow{2}{*}{$273 \mathrm{bp}$} \\
\hline & ASGV_R (3'oligo) & TTACTCTCCGAACCTGCCTC & & \\
\hline & ASGV_F_484bp (5'oligo) & CATCTGATAAGACCCAGTTTCC & & \multirow{2}{*}{$484 \mathrm{bp}$} \\
\hline & ASGV_R_484bp (5'oligo) & TTACTCTCCGAACCTGCCTC & & \\
\hline & \multicolumn{4}{|c|}{ For amplifying complete ASGV CP } \\
\hline & ASGV_CP_F (5'oligo) & AAA GTCGAC ATGAGTTTGGAAGACGTGCTTC & SalI & \multirow{2}{*}{$714 \mathrm{bp}$} \\
\hline & ASGV_CP_R(3'oligo) & AAA GGATCC CTAACCCTCCAGTTCCAGGTTAC & ВатHI & \\
\hline \multirow{6}{*}{ ACLSV } & For ACLSV diagnosis & & & \\
\hline & ACLSV_F (5'oligo) & TTCATGGAAAGACAGGGGCAA & \multirow{2}{*}{ Menzel et al (2002) } & \multirow{2}{*}{$677 \mathrm{bp}$} \\
\hline & ACLSV_R (3'oligo) & AAGTCTACAGGCTATTTATTATAAGTCTAA & & \\
\hline & \multicolumn{4}{|c|}{ For amplifying complete ACLSV MP } \\
\hline & ACLSV_MP_F(5'oligo) & AAA GTCGAC ATGATGATAAGGGGTCAC & SalI & \multirow{2}{*}{$1377 \mathrm{bp}$} \\
\hline & ACLSV_MP_R(3'oligo) & AAA GGGCCC TCACACACCTGGCGGAAAG & Apa I & \\
\hline
\end{tabular}

${ }^{a}$ Apple stem grooving virus

${ }^{\mathrm{b}}$ Apple chlorotic leaf spot virus

(Promega Co., Ltd.) or T-blunt ${ }^{\mathrm{TM}}$ vector (Solgent Co., Ltd.). Plasmids with PCR product inserts were confirmed using restriction enzyme digestion with SalI and BamHI for ASGV CP, or SalI and ApaI for ACLSV MP (New England BioLabs ${ }^{\circledR}$ Inc.). Positive plasmids were sequenced by Macrogen Inc.

\section{SEQUENCE ANALYSIS AND PHYLOGENETIC TREE CONSTRUCTION}

The nucleotide sequences and amino acid sequences were compared using DNAMAN (Version 5. 2.10, Lynnon BioSoft). Phylogenetic trees were constructed using neighbor-joining method with 1,000 bootstrap replicates in the MEGA version 6 (Tamura et al., 2013). 17 ACLSV MP nucleotide sequences and 30 ASGV CP nucleotide sequences were obtained from NCBI GenBank. Cherry mottle leaf virus (CMLV; genus: Trichovirus) MP nucleotide sequence and Cherry virus A (CVA; genus: Capillovirus) CP nucleotide sequence were used as the outgroup for ACLSV and ASGV phylogenetic trees respec- tively.

\section{RESULTS AND DISCUSSION}

\section{DISTRIBUTION OF APPLE VIRUSES}

In order to investigate the occurrence of apple viruses in Korea, total 65 suspected virus-infected apple samples were subjected to RT-PCR. Among these 65 samples, 22 were positive for ASGV (33.8\%), three samples were positive for ACLSV (4.6\%) and dual infections of ASGV and ACLSV were diagnosed in two samples (3.1\%) (Table 2). ASGV occurrence was confirmed throughout the entire collection region. The ASGV infection ratio was 48\% in Gyeongsang Province and 25\% in Chungcheong Province. However, ACLSV occurred at only two sites (Gunwi and Chungju) with an infection ratio of $8 \%$ in Gyeongsang Province and $2.5 \%$ in Chungcheong Province.

In an earlier survey of Korean apples, the infection ratio of ASGV was $35.2 \%$, that of ACLSV was 50.9\% and

Table 2. Regional virus diagnosis results

\begin{tabular}{rlccc}
\hline Province & Region & ASGV positive & ACLSV positive & Double infection \\
\hline \multirow{5}{*}{ Gyeongsang } & Gunwi & $9 / 16$ & $2 / 16$ & $1 / 16$ \\
& Cheongsong & $1 / 7$ & $0 / 7$ & $0 / 7$ \\
& Changwon & $2 / 2$ & $0 / 2$ & $1 / 25(4 \%)$ \\
\hline \multirow{5}{*}{ Chungcheong } & Total & $12 / 25(48 \%)^{\text {a }}$ & $2 / 25(8 \%)$ & $0 / 25$ \\
& Yesan & $6 / 25$ & $0 / 25$ & $1 / 15$ \\
& Chungju & $4 / 15$ & $1 / 15$ & $1 / 40(2.5 \%)$ \\
\hline
\end{tabular}

a positive samples/samples tested, diagnosis (percentage) 
double infection of ASGV and ACLSV was 19.6\% (Park et al., 2006). In contrast to those results, ACLSV infection ratio was $4.6 \%$ in this study. However, the ASGV infection ratio in the current study slightly higher, at 48\% in Gyeongsang province. Cho et al. (2010) reported that infection rates of ASGV and ACLSV were $74.24 \%$ and $0.4 \%$ respectively in Korean pears. Although based on relatively small sample sizes, these numbers suggest that infection rates differ between orchards, and between apples and pears, but imply that prevention against viruses has been ineffective or not performed in Korea orchards.

\section{SEQUENCE VARIABILITY OF CP GENE OF ASGV AND MP GENE OF ACLSV}

All virus positive samples were subjected to PCR to amplify the complete ASGV CP or ACLSV MP gene. ASGV CP is a conserved region that is under negative selection (Liebenberg et al., 2012) and has been used for ASGV phylogenetic analysis (Lui et al., 2013; Shim et al., 2006; Bhardwaj et al., 2014;). ACLSV MP, which is also known to function as a systemic silencing suppressor, has been well studied for its biological features and mechanisms (Yoshikawa et al., 1999, 2000, 2006; Satoh et al., 2000; Isogai et al., 2003; Isogai and Yoshikawa, 2005; Yaegashi et al., 2007, 2008).

Eighteen ASGV isolates were obtained from all regions and 6 ACLSV isolates were obtained from Gunwi (Table 3). Although ACLSV was detected from one Chungju sample, we failed to obtain a full-length ACLSV MP product from this sample. This failure may have been due to sequence variability with the 5' or 3' terminal regions targeted by the ACLSV MP primers.

The nucleotide sequences and amino acid sequences of the isolates were compared using DNAMAN (Version 5.2.10). The results indicated that ASGV isolate pairwise identity was an average of $99.16 \%$ (nucleotide) and 98.95\% (amino acid). ACLSV isolates showed an average of 92.06\% (nucleotide) and 95.09\% (amino acid) identity.

Phylogenetic trees were constructed based on the CP nucleotide sequences of 18 Korean ASGV isolates from this study and 30 additional ASGV isolates from NCBI, and on the MP nucleotide sequences of 6 Korean ACLSV isolates from this study and 17 other isolates from NCBI GenBank (Figure 3). The GenBank sequences originate from various countries and hosts. ASGV isolates are separated into three groups: ASGV CP Group 1 included 18 isolates from this study, 2 isolates from Indian kiwi and 4 isolates from Chinese apple. Groups 2 and 3 include isolates from multiple countries and hosts. ACLSV MP sequences were separated into 2 groups, of which Group 1 separated into three subgroups. Isolates from this study were all included in Group 1. Subgroup 1A included CLGW1, CLGW2 and 4 isolates from Japanese

Table 3. Regions and accession numbers of isolates of this study (Accessions are being processed)

\begin{tabular}{|c|c|c|c|}
\hline Virus & Isolate & Region & Accession number \\
\hline \multirow{18}{*}{ Apple stem grooving virus } & GW2 & \multirow{3}{*}{ Gunwi } & KR606307 \\
\hline & GW3 & & KR606308 \\
\hline & GW4 & & KR606309 \\
\hline & YS1 & \multirow{5}{*}{ Yesan } & KR606310 \\
\hline & YS4 & & KR606311 \\
\hline & YS5 & & KR606312 \\
\hline & YS8 & & KR606313 \\
\hline & YS10 & & KR606314 \\
\hline & CS3 & \multirow{5}{*}{ Cheongsong } & KR606315 \\
\hline & CS6 & & KR606316 \\
\hline & CS7 & & KR606317 \\
\hline & CS8 & & KR606318 \\
\hline & CS9 & & KR606319 \\
\hline & CJ6 & \multirow{3}{*}{ Chungju } & KR606320 \\
\hline & CJ16 & & KR606321 \\
\hline & CJ17 & & KR606322 \\
\hline & CW6 & \multirow{2}{*}{ Changwon } & KR606323 \\
\hline & CW8 & & KR606324 \\
\hline \multirow{6}{*}{ Apple chlorotic leaf spot virus ${ }^{b}$} & GW1 & \multirow{6}{*}{ Gunwi } & KR606325 \\
\hline & GW2 & & KR606326 \\
\hline & GW3 & & KR606327 \\
\hline & GW4 & & KR606328 \\
\hline & GW6 & & KR606329 \\
\hline & GW8 & & KR606330 \\
\hline
\end{tabular}


and Chinese apple. Subgroup 1B included CLGW3, CLGW6, one isolate from Indian apple, 3 isolates from French, Chinese, and German plum. Subgroup 1C included CLGW4, CLGW8 and 4 isolates from only Japanese apple. Group 2 included 3 isolates from Chinese pear, 1 Chinese hawthorn isolate and 1 Japanese apple isolate.

Two Korean ASGV CP isolates from GenBank (A50:
Cheongsong, A67: Chungju) are from the same regions as some isolates of this study (CS3, 6, 7, 8, 9: Cheongsong, C6, 16, 17: Chungju). However, the phylogenetic tree (Figure 3A) separated these isolates into three distinct groups. The collection year of isolates A50 and A67 was 2008 and 2009 respectively. These data suggest that the new ASGV isolates detected in Korea may have been introduced from either China or India. Korean ACLSV
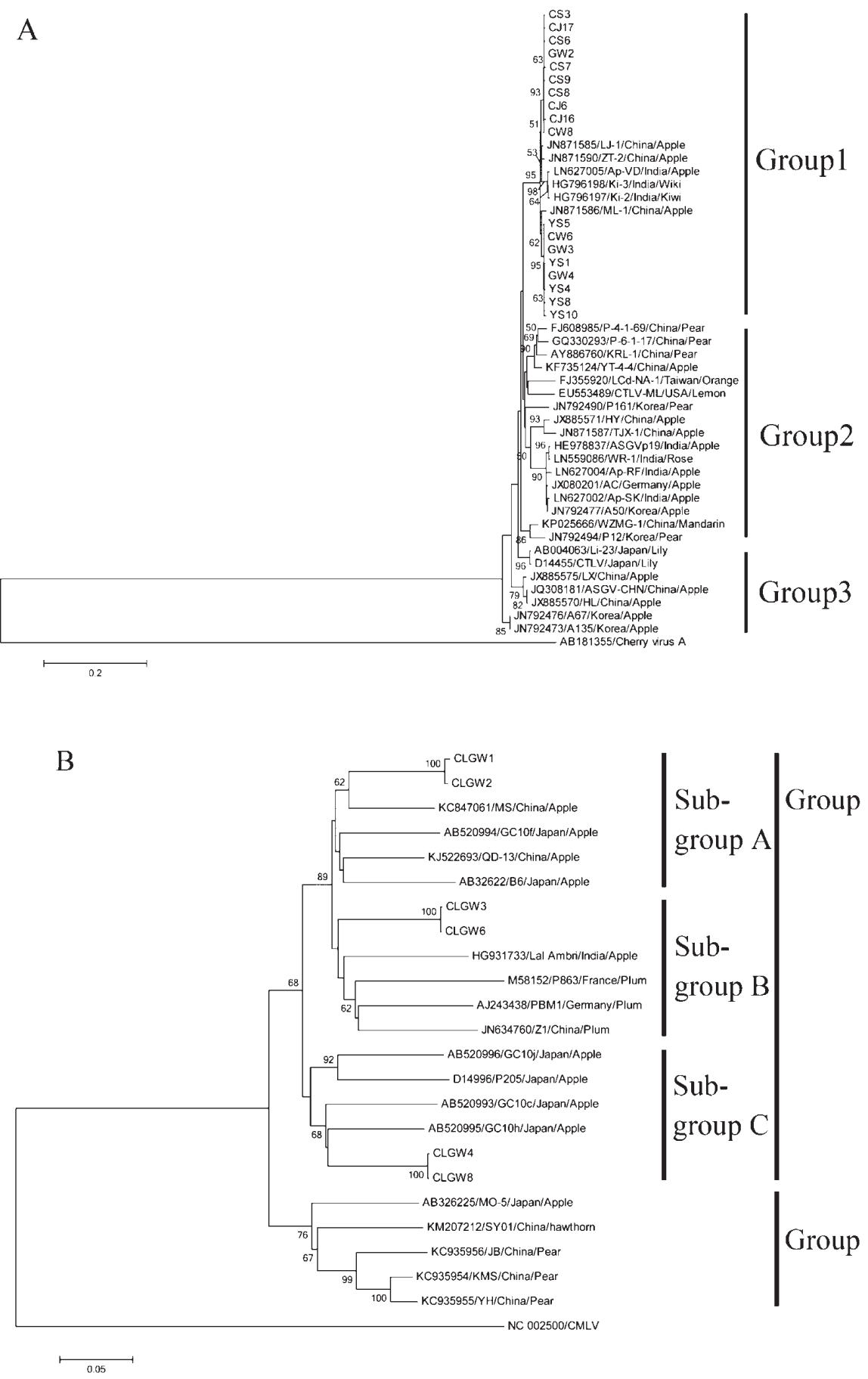

Fig. 3. Phylogenetic tree based on Apple stem grooving virus coat proteins(A) and Apple chlorotic leaf spot virus movement proteins(B). The trees were constructed with MEGA 6.0 using Neighbor-joining method with 1,000 bootstrap replicates. 30 isolates of ASGV CP and 17 isolates of ACLSV MP for analysis were obtained from National Center for Biotechnology Information GenBank. The name indicates Accession numbers/name of isolate/country/host. The number at the nodes is bootstrap values above $50 \%$. The scale bars indicate the number of nucleotide substitutions. CMLV = Cherry mottle leaf virus. 
isolates have been poorly investigated to date; there is only one prior nucleotide sequence (Accession number: LC006864) and the corresponding amino acid sequence (BAP81778) of partial ACLSV CP. The current study is the first report of the MP sequences of Korean ACLSV isolates and phylogenetic analysis. The Group 1 of the ACLSV MP tree (Fig. 3 B) is separated into three subgroups. Each subgroup was divided by countries and host of isolates. Considering that the isolates from this study were from single region, Gunwi, and divided between all 3 subgroups, we suggest that there are at least three distinct subgroups of ACLSV isolates in Korea, and that more biological and phylogenetic data are needed to trace the potential origins of ACLSV isolates in Korea.

ASGV prevalence has remained high since 2006. The nucleotide and amino acid identity of the isolates in this study was above $98 \%$, and the phylogenetic tree showed that isolates from all collection sites were clustered in a single group with Chinese and Indian isolates. However, previously reported Korean isolates were phylogenetically distinct from the isolates identified in this study, but group with additional sequences from China and India. This suggests that the ASGV isolates from different orchards came from a limited number of sources, but likely originate from either China or India, and have been distributed within Korea with either budwood (most likely) or rootstocks. In contrast, ACLSV was much less prevalent in the orchards tested, but isolates showed greater sequence diversity (only $92-95 \%$ identity between isolates) and were distributed among three subgroups of isolates with multiple countries of origin, This suggests at least three separate introductions into Korea, and the potential for recombination between isolates or transmission to other hosts. ASGV and ACLSV are both transmitted by grafting sensitive rootstock and virus infected scions. Both viruses may also be mechanically transmitted to some diagnostic species (e.g. Chenopodium quinoa etc.) (Yanase, 1982; Llacer et al., 1985; Kinard and Scott, 1996). Thus, supply and usage of healthy scion and resistant rootstock is important in order to prevent spread of these apple viruses. A national survey of apple viruses should be performed routinely, and additional biological and phylogenetic studies of Korean ASGV and ACLSV isolates should be accomplished. Virus-certified budwood and rootstocks should be produced and made available for establishment of new orchards to allow eventual elimination of infected orchards.

\section{ACKNOWLEDGEMENT}

This research was supported by iPET (Korea Institute of Planning and Evaluation for Technology in Food, Agriculture, Forestry and Fisheries), Ministry of Agriculture, Food and Rural Affairs (Project No. 1120183) and carried out with the support of "Cooperative Research Program for Agriculture Science and Technology Development (Project No. PJ01007703201401) J01007703201401 the support of "Cooperative Research.

\section{REFERENCES}

Bhardwaj, P., R. Ram, A. A. Zaidi and V. Hallan 2014 Characterization of Apple stem grooving virus infecting Actinidia deliciosa (Kiwi) in India. Sci. Hortic., 176: 105111

Campbell, A. 1963 The effect of some latent virus infections on the growth and cropping of Apples. J. Hort. Sci., 38(1): 15-19

Cembali, T., R. J. Folwell, P. Wandschneider, K. C. Eastwell and W. E. Howell 2003 Economic implications of a virus prevention program in deciduous tree fruits in the US. Crop Protection, 22(10): 1149-1156

Chang, S., J. Puryear and J. Cairney 1993 A simple and efficient method for isolating RNA from pine trees. Plant Mol. Biol. Rep., 11(2): 113-116

Cho, I. S., D. H. Kim, H. R. Kim, B. N. Chung, J. D. Cho and G. S. Choi 2010 Occurrence of pome fruit viruses on pear trees (Pyrus pyrifolia) in Korea. Res. Plant Dis., 16: 326-330

Clover, G. R. G., M. N. Pearson, D. R. Elliott, Z. Tang, T. Smales and B. J. R. Alexander 2003 Characterization of a strain of Apple stem grooving virus in Actinidia chinensis from China. Plant Pathol., 52(3): 371-378

Duan, H., Z. Ji, S. Wang, T. Hu, Y. Wang and K. Cao 2014 Molecular Characterization and Distribution of Apple Chlorotic Leaf Spot Virus on Apple in China. J. Phytopathol., 162(5): 284-290

Foissac, X., L. Svanella-Dumas, P. Gentit, M. J. Dulucq, A. Marais and T. Candresse 2005 Polyvalent degenerate oligonucleotides reverse transcription-polymerase chain reaction: a polyvalent detection and characterization tool for trichoviruses, capilloviruses, and foveaviruses. Phytopathology, 95(6): 617-625

German, S., T. Candresse, M. Lanneau, J. C. Huet, J. C. Pernollet and J. Dunez 1990 Nucleotide sequence and genomic organization of apple chlorotic leaf spot closterovirus. Virology, 179(1): 104-112

Hirata, H., X. Lu, Y. Yamaji, S. Kagiwada, M. Ugaki and S. Namba 2003 A single silent substitution in the genome of Apple stem grooving virus causes symptom attenuation. J. Gen. Virol., 84(9): 2579-2583

Isogai, M., Y. Saitou, N. Takahashi, T. Itabashi, M. Terada, H. Satoh and N. Yoshikawa 2003 The 50-kDa protein of Apple chlorotic leaf spot virus interferes with intracellular and intercellular targeting and tubule-inducing activity of the 39-kDa protein of Grapevine berry inner necrosis virus. Mol. Plant Microbe Interact., 16(3): 188-195

Isogai, M. and N. Yoshikawa 2005 Mapping the RNA-binding domain on the Apple chlorotic leaf spot virus movement protein. J. Gen. Virol., 86(1): 225-229

Ji, Z., X. Zhao, H. Duan, T. Hu, S. Wang, Y. Wang and K. Cao 2013 Multiplex RT-PCR detection and distribution of four apple viruses in China. Acta Virol., 57(4): 435-441

Jones, R. A. 2009 Plant virus emergence and evolution: origins, new encounter scenarios, factors driving emergence, effects of changing world conditions, and prospects for control. Virus Res., 141(2): 113-130

Kim, J. S., S. H. Lee, H. S. Choi, M. K. Kim, H. R. Kwak, M. Nam and B. N. Chung 2011 Occurrence of Virus Diseases on Major Crops in 2010. Res. Plant Dis., 17(3): 334-341

Kinard, G. and S. Scott 1996 Detection of Apple Chlorotic Leaf Spot and Apple Stem Grooving Viruses Using RT-PCR. Plant Dis., 80(6): 616-621

Kirby, M. J., C. M. Guise, and A. N. Adams 2001 Comparison of bioassays and laboratory assays for apple stem grooving virus. J. Virol. Methods, 93(1-2): 167-173

Kumar, S., R. M. Singh, R. Ram, J. Badyal, V. Hallan, A. A. Zaidi and A. Varma 2012 Determination of major viral and sub viral pathogens incidence in apple orchards in Himachal Pradesh. Indian J. Virol., 23(1): 75-79

Liebenberg, A., B. Moury, N. Sabath, R., Hell, A. Kappis, W. Jarausch and T. Wetzel 2012 Molecular evolution of the genomic RNA of Apple stem grooving Capillovirus. J. Mol. 
Evol., 75(3-4): 92-101

Lister, R., J. Bancroft and N. MJ 1965 Some sap-transmissible viruses from apple. Phytopathology, 55(8): 859-\&

Liu, P., Z. Li, S. Song and Y. Wu 2014 Molecular variability of Apple chlorotic leaf spot virus in Shaanxi, China. Phytoparasitica, 42(4): 445-454

Liu, P., L. Zhang, H. Zhang, H. Jiao and Y. Wu 2013 Detection and Molecular Variability of Apple Stem Grooving Virus in Shaanxi, China. J. Phytopathol., 161(6): 445-449

Llacer, G., M. Cambra, A. Lavina and J. Aramburu 1985 Suitable conditions for detecting apple chlorotic leaf spot virus in apricot trees by enzyme-linked immunosorbent assay (ELISA). Agronomie, 5(9): 809-812

Marinho, V. L. A., J. Daniels, J. Kummert, A. Chandelier and P. Lepoivre 2003 RT-PCR-ELISA for detection of Apple stem grooving virus in apple trees. Fitopatol. Bras., 28(4): 374379

Menzel, W., W. Jelkmann and E. Maiss 2002 Detection of four apple viruses by multiplex RT-PCR assays with coamplification of plant mRNA as internal control. J. Virol. Methods, 99(1-2): $81-92$

Nam, K. W. and K. S. Kim 2002 Graft transmission and cytopathology of pear black necrotic leaf spot (PBNLS) disease. Plant Pathol. J., 18(6): 301-307

Nemeth, M. 1986 Virus, mycoplasma and Rickettsia diseases of fruit trees. Martinus Nijhoff/Dr W: Junk Publishers, Dordrecht, Boston, Lancaster. p. 841

Park, H. L., J. E. Yoon, H. R. Kim and K. H. Baek 2006 Multiplex RT-PCR Assay for the Detection of Apple stem grooving virus and Apple chlorotic leaf spot virus in Infected Korean Apple Cultivars. Plant Pathol. J., 22(2): 168

Posnette, A. F., R. Cropley and C. Ellemberger 1963 The effect of virus infection on the growth and crop of apple, pear and plum trees. Phytopathol. Mediterr., 2: 158-161

Pūpola, N., I. Moročko-Bičevska, A. Kāle and A. Zeltinš 2011 Occurrence and diversity of pome fruit viruses in apple and pear orchards in Latvia. J. Phytopathol., 159(9): 597-605

Roy, A., A. Fayad, G. Barthe and R. H. Brlansky 2005 A multiplex polymerase chain reaction method for reliable, sensitive and simultaneous detection of multiple viruses in citrus trees. $J$. Virol. Methods, 129(1): 47-55

Sato, K., N. Yoshikawa and T. Takahashi 1993 Complete nucleotide sequence of the genome of an apple isolate of apple chlorotic leaf spot virus. J. Gen. Virol., 74(9): 1927-1931

Satoh, H., H. Matsuda, T. Kawamura, M. Isogai, N. Yoshikawa and T. Takahashi 2000 Intracellular distribution, cell-to-cell trafficking and tubule-inducing activity of the $50 \mathrm{kDa}$ movement protein of Apple chlorotic leaf spot virus fused to green fluorescent protein. J. Gen. Virol., 81(8): 2085-2093

Schmidt, H. 1972 The effect of 'latent' virus infections on the yield of maiden trees on 20 apomictic Apple seedling rootstocks. $J$. Hort. Sci., 47(2): 159-163

Shim, H., Y. Min, S. Hong, M. Kwon, D. Kim, H. Kim and J. Yang 2004 Nucleotide sequences of a Korean isolate of apple stem grooving virus associated with black necrotic leaf spot disease on pear (Pyrus pyrifolia). Mol. Cells, 18(2): 192-199
Song, Y., N. Hong, L. Wang, H. Hu, R. Tian, W. Xu and G. Wang 2011 Molecular and serological diversity in Apple chlorotic leaf spot virus from sand pear (Pyrus pyrifolia) in China. Eur. J. Plant Pathol., 130(2): 183-196

Tamura, K., G. Stecher, D. Peterson, A. Filipski and S. Kumar 2013 MEGA6: molecular evolutionary genetics analysis version 6.0. Mol. Biol. Evol., 30(12): 2725-2729

Tatineni, S., M. R. Afunian, S. Gowda, M. E. Hilf, M. Bar-Joseph and W. O. Dawson 2009 Characterization of the 5'-and 3'-terminal subgenomic RNAs produced by a capillovirus: Evidence for a CP subgenomic RNA. Virology, 385(2): 521-528

Wang, L., N. Hong, S. Matić, A. Myrta, Y. Song, R. Michelutti and G. Wang 2011 Pome fruit viruses at the Canadian Clonal Genebank and molecular characterization of Apple chlorotic leaf spot virus isolates. Sci. Hort., 130(3): 665-671

Yaegashi, H., T. Takahashi, M. Isogai, T. Kobori, S. Ohki and N Yoshikawa 2007 Apple chlorotic leaf spot virus $50 \mathrm{kDa}$ movement protein acts as a suppressor of systemic silencing without interfering with local silencing in Nicotiana benthamiana. J. Gen. Virol., 88(1): 316-324

Yaegashi, H., A. Tamura, M. Isogai and N. Yoshikawa 2008 Inhibition of long-distance movement of RNA silencing signals in Nicotiana benthamiana by Apple chlorotic leaf spot virus $50 \mathrm{kDa}$ movement protein. Virology, 382(2): 199-206

Yanase, H. 1982 Back-transmission of Apple stem grooving virus to apple seedlings and induction of symptoms of apple topworking disease in Mitsuba kaido (Malus sieboldii) and Kobano zumi (Malus sieboldii var. arborescens) rootstocks. Paper presented at the XII International Symposium on Fruit Tree Virus Diseases 130

Yanase, H., G. Mink, K. Sawamura and A. Yamaguchi 1990 Apple topworking disease. In "Compendium of Apple and Pear Diseases", ed. by A. L. Jones and H. S. Aldwinckle, Amer Phytopathological Society, St. Paul, MN, pp. 74-75

Yoshikawa, N., E. Sasaki, M. Kato and T. Takahashi 1992 The nucleotide sequence of apple stem grooving capillovirus genome. Virology, 191(1): 98-105

Yoshikawa, N., S. Oogake, M. Terada, S. Miyabayashi, Y. Ikeda, T. Takahashi and K. Ogawa 1999 Apple chlorotic leaf spot virus $50 \mathrm{kDa}$ protein is targeted to plasmodesmata and accumulates in sieve elements in transgenic plant leaves. Arch. Virol., 144(12): 2475-2483

Yoshikawa, N., S. Gotoh, M. Umezawa, N. Satoh, H. Satoh, T. Takahashi and K. Yoshida 2000 Transgenic Nicotiana occidentalis plants expressing the 50-kDa protein of Apple chlorotic leaf spot virus display increased susceptibility to homologous virus, but strong resistance to Grapevine berry inner necrosis virus. Phytopathology, 90(3): 311-316

Yoshikawa, N., Y. Saitou, A. Kitajima, T. Chida, N. Sasaki and M. Isogai 2006 Interference of long-distance movement of Grapevine berry inner necrosis virus in transgenic plants expressing a defective movement protein of Apple chlorotic leaf spot virus. Phytopathology, 96(4): 378-385

Zahn, V. 1996 Obstvirustestung im Wandel der Zeit. Obstbau, 21: $547-550$ 